\title{
Growth Inhibition Potentials of Leaf Extracts from Four Selected Euphorbiaceae against Fruit Rot Fungi of African Star Apple (Chrysophyllum albidum G. Don)
} llondu EM ${ }^{1}$ and Bosah BO $^{2}$

${ }^{1}$ Department of Botany, Faculty of Science, Delta State University, Abraka, Nigeria

${ }^{2}$ Department of Agronomy, Faculty of Agriculture, Delta State University, Asaba Campus, Nigeria

\begin{abstract}
The efficacy of ethanolic leaf extracts from Phyllanthus amarus, Euphorbia hirta, Euphorbia heterophylla and Acalypha fimbriata in inhibiting the growth of post-harvest fruit rot fungi of Chrysophyllum albidum was investigated at the concentrations of $100,80,6040$ and $20 \mathrm{mg} / \mathrm{ml}$ in-vitro. The fungi isolated from rotted fruits and their frequency of occurrence includes Aspergillus niger (69.6\%) and Fusarium solani (30.4\%). These fungal isolates were cultured on different leaf extracts agar and their radial mycelia growth was observed. The antifungal activities increased with increase in concentrations of the plant extracts with $E$. heterophylla extract most effective in inhibiting the growth of $A$. niger while $A$. fimbriata extract was more effective in the inhibition of $F$. solani than other extracts. Phytochemical screening of the plant extracts revealed the presence of saponins, alkaloids, glycosides, terpenes, steroids, flavonoids, tannins and phenols. Gas Chromatography Mass Spectrometry (GC-MS) analysis revealed the presence a complex mixture of constituents ranging from 7 compounds in $E$. hirta, 10 compounds in $A$. fimbriata, 11 compounds in E. heterophylla and 14 compounds in $P$. amarus. The result of this study is an indication that these Euphorbiaceae could be a potential source of antifungal agents.
\end{abstract}

Keywords: Growth inhibition; Leaf extracts; Euphorbiaceae; Rot fungi; Chrysophyllum albidum

\section{Introduction}

Chrysophyllum albidum G. Don commonly called African star apple and locally called udara (Igbo), agbalumo (Yoruba) belongs to the family Sapotaceae [1]. It features prominently in the compound agro forestry system for fruit, food, cash income and other auxiliary uses including environmental purposes. It is also a tree that is common throughout the Tropical Central, East and West Africa regions for its sweet edible fruit and various ethnomedical uses [2].

C. albidum fruits are widely eaten in Southern Nigeria. The fruit is seasonal (December-March), when ripe. It is flattened seeds or sometimes fewer by abortion. The fruit is ovoid to sub-globose pointed at the apex and up to $6 \mathrm{~cm}$ long and $5 \mathrm{~cm}$ in diameter. The skin or peel is grey when immature turning orange red, pinkish or light yellow within the pulp having three to five seeds arranged as a star [3].

The fruit has been found to have the highest content of ascorbic acid with 1000 to $3330 \mu \mathrm{g}$ of ascorbic acid per $100 \mathrm{gm}$ of edible fruit or about 100 times that of oranges and 10 times of that of guava or cashew. It is also an excellent source of vitamins B and D as well as iron [4]. Umoh [5] and Ureigho [6] reported on the proximate composition, minerals and vitamins content of Chrysophyllum albidum.

The fruit has immense economic potential, especially following the report that jams that could compete with rasp berry jams and jellies could be made from it and it is eaten especially as snack by both young and old [2]. The fruits contain $90 \%$ anacadic acid, which is used industrially in protecting wood and as a source of resin. The fruits can be used in the preparation of wine, soft drink, jams and jellies $[3,6]$.

The seed are used for local games; it is also a source of oil, which used for diverse purposes [7]. The seeds along with those of other Sapotaceae are used as anklets in dancing. It was also discovered in the removal of $\mathrm{Ni}^{2+}$ ions from synthetic wastewater [8]. The cotyledons are useful in the preparation of medicine for the treatment of infertility problems in both male and female; infertility due to the presence of abnormalities within the uterus and female tubes, abdominal pains in dysmenorrheal, secondary ammenorrhae in women (loss or absence of menstrual cycle). The seed cotyledon has been reported to possess antihyperglycemic and hypolipidemic effects [9].

Fungi have been reported to be associated with post harvest deterioration of agricultural products in Nigeria. However, F. solani, L. theobromae, Rhizopus spp and A. flavus have been reported to be associated with C. albidum [10]. Since most microbial spores are small in size and light, they could settle on the surface of African Star Apple fruits resulting in the range of microbial group isolated from them.

Preserving the freshness of these fruits for many days or months is therefore the problem, which most farmers and the traders seek to solve. Control of fruit rot by employing the use of local preservatives (plant extracts) like Afromomum danielli, Afromomum melegueta and chemical disinfectants like (parazone), sodium chloride and sodium benzoate at mild form has been suggested to reduce the losses due to storage moulds [10].

The objective of this study is therefore to isolate and identify fungi associated with C. albidum fruits rot in storage as well as to

*Corresponding author: llondu EM, Department of Botany, Faculty of Science, Delta State University, Abraka, Nigeria, Tel: +2348036758249; E-mail: martinailondu@yahoo.co.uk

Received September 07, 2015; Accepted October 07, 2015; Published October 11,2015

Citation: Ilondu EM, Bosah BO (2015) Growth inhibition potentials of Leaf Extracts from Four Selected Euphorbiaceae against Fruit Rot Fungi of African Star Apple (Chrysophyllum albidum G. Don). J Plant Pathol Microb 6: 306. doi:10.4172/21577471.1000306

Copyright: $\odot 2015$ llondu EM, et al. This is an open-access article distributed under the terms of the Creative Commons Attribution License, which permits unrestricted use, distribution, and reproduction in any medium, provided the original author and source are credited. 
Citation: Ilondu EM, Bosah BO (2015) Growth inhibition potentials of Leaf Extracts from Four Selected Euphorbiaceae against Fruit Rot Fungi of African Star Apple (Chrysophyllum albidum G. Don). J Plant Pathol Microb 6: 306. doi:10.4172/2157-7471.1000306

determine the effects of various concentrations of ethanolic extracts of Phyllanthus amarus, Euphorbia hirta, Euphorbia heterophylla and Acalypha fimbriata on the identified fungi.

\section{Materials and Methods}

\section{Collection of plant materials for the study}

Mature healthy and rotted C. albidum fruits were purchased at Abraka Main Market, Delta State. Fresh and healthy leaves of Euphorbia hirta, Euphorbia heterophylla Phyllantus amarus and Acalypha fimbriata free from insect and pathogen attack were collected from different areas within Abraka community. Abraka (Ethiope East Local Government Area of Delta State lies within latitude $05^{\circ} 47^{\prime \prime} \mathrm{N}$ and longitude $06^{\circ} 06^{\prime \prime} \mathrm{E}$ of the Equator with an annual rainfall of 3,097.8 $\mathrm{mm}$, annual relative humidity of $83 \%$ and annual mean temperature of $30.6^{\circ} \mathrm{C}$ [11]. The plants were identified using Akobundu and Agyakwa [12].

\section{Isolation and identification of fungi}

Isolation and identification of fungi from diseased C. albidum fruits was carried out using the method adopted from Ilondu [13]. Sections, $4 \mathrm{~mm}$ long, excised from the margins of diseased spot with sterile razor blade were surface-sterilized for $2 \mathrm{~min}$ in $2 \%$ aqueous solution of commercial bleach (sodium hypochlorite solution), rinsed in two changes of sterile distilled water. The disinfected tissue pieces were blotted between sterile Whatman No. 1 filter paper and aseptically plated on potato dextrose agar (PDA) plates ( 3 pieces per plate). The plates were then incubated at room temperature $\left(32 \pm 2^{\circ} \mathrm{C}\right)$ for five days. Any observed mycelial growth was repeatedly transferred to fresh PDA plates until pure cultures of isolates were obtained.

The frequency of isolations of the different types of fungi associated with C. albidum fruit rot diseases was determined. The number of times each fungus was encountered was recorded. The percentage frequency of occurrence was calculated with the formula below:

$\frac{\text { Number of times a fungus was encountered }}{\text { Total fungal isolations }} \times \frac{100}{1}$

\section{Plant sample preparation and extraction procedures}

The plants were collected into polyethylene bags and taken to the laboratory for processing. The leaves were separately plucked and rinsed in flowing tap water, shade dried on the bench in a ventilated section of the Department of Botany herbarium at ambient temperature $\left(30^{\circ} \mathrm{C} \pm\right.$ 2 ) for two weeks [14]. Dried leaves were separately ground into powder using an electric blender before extraction. For extraction procedures, one hundred gram of each pulverized sample was put into Soxhlet extractor and three hundred milliliter of absolute ethanol (HPLC grade) was added and extracted for $8 \mathrm{hrs}$ for each batch of sample. The extracts were evaporated on a rotary evaporator at $40^{\circ} \mathrm{C}$ to remove excess alcohol. The solvent free extracts were stored at $4^{\circ} \mathrm{C}$ till needed.

\section{Phytochemical tests}

One gram of powdered sample was subjected to phytochemical test for alkaloid (Myers reagent), Flavonoids were determined by magnesium rebbon test, Sapoins by chloroform and $\mathrm{H}_{2} \mathrm{SO}_{4}$ tests, Tannins, by Ferric salt test, Sterol by Chloroform-acetic anhydride, Terpenes and phenols by following the procedures of Oyewale and Audu [15].

\section{Extract analysis}

GC-MS analysis was done at National Research Institute for
Chemical Technology (NARICT) Zaria, Kaduna state, Nigeria. A SHIMADZU GCMS-QP 2010 Plus system was used. The GC-MS was operated under the following conditions: Column oven temperature: $70^{\circ} \mathrm{C}$; Injection temperature: $250^{\circ} \mathrm{C}$; Injection mode: split; Pressure: $104.1 \mathrm{kPa}$; Total flow: $6.2 \mathrm{ml} / \mathrm{min}$; Column flow: $1.59 \mathrm{ml} / \mathrm{min}$; Linear velocity: $46.3 \mathrm{~cm} / \mathrm{sec}$; Purge flow: $3.0 \mathrm{~mL} / \mathrm{min}$; and Split ratio: 1.0. The generated chromatogram was recorded. The identification of the components was carried out using the peak enrichment technique of reference compounds and computer matching with those of NIST.05 library mass spectrum $[14,16]$.

\section{Effect of extracts on fungal growth}

Different concentrations $(100,80,6040$ and $20 \mathrm{mg} / \mathrm{ml})$ were prepared from each of the extracts. One millilitre of each level of concentration was aseptically incorporated into $20 \mathrm{ml}$ of cool molten PDA in sterile test tube. Each medium was homogenized by gentle agitation before dispensing into sterile $9 \mathrm{~cm}$ Petri dishes. The control was set up using extract free PDA plates. The plates were allowed to set for $3 \mathrm{hr}$. The effect of the extracts on fungal growth was determined using the method of Chohan et al. [17]. This was done by inoculating at the Centre of $90 \mathrm{~cm}$ Petri plates with a mycelia disc $(4 \mathrm{~mm})$ obtained from the colony edge of 7-day old culture of the test fungi. Three replicates of both the control and PDA-extract plates per isolate were incubated at room temperature $\left(28 \pm 2^{\circ} \mathrm{C}\right)$ and radial growth was measured with a metric ruler daily for seven days. Colony diameter was taken as the means along two directions on two perpendicular lines drawn on the reverse of the plates. The percentage inhibition was calculated by the method of Ayodele et al. [18].

\section{Data analysis}

Data obtained were subjected to Analysis of Variance (ANOVA) using Statistical Package for Social Science (SPSS) version 17.0 and means were separated according to Duncan's Multiple Range Test (DMRT) at $5 \%$ probability level.

\section{Results}

The fungi isolated from the diseased Chrysophyllum albidum fruits were Aspergillus niger and Fusarium solani. A. niger occurred more frequently with $69.6 \%$ followed by $F$. solani with $30.4 \%$ (Table 1 ). The classes of natural products present in the plant investigated are shown in Table 2. Tannins, saponins, steroids and phenols were present in all

\begin{tabular}{|c|c|c|c|}
\hline Fungal isolate & $\begin{array}{c}\text { No of times } \\
\text { isolated }\end{array}$ & $\begin{array}{c}\text { Percentage } \\
\text { frequency (\%) }\end{array}$ & $\begin{array}{c}\text { Pathogenicity of } \\
\text { isolates }\end{array}$ \\
\hline Aspergillus niger & 80 & 69.6 & + \\
\hline Fusarium solani & 35 & 30.4 & + \\
\hline
\end{tabular}

Table 1: Percentage occurrence of fungi associated with Chrysophyllum albidum.

\begin{tabular}{|c|c|c|c|c|}
\hline Phytochemicals & $\boldsymbol{P}$. amarus & E. hirta & E. heterophylla & A. fimbriata \\
\hline Saponins & + & + & + & + \\
\hline Alkaloids & - & + & + & + \\
\hline Tannins & + & + & + & + \\
\hline Flavonoids & - & + & - & - \\
\hline Steroids & + & + & + & + \\
\hline Glycosides & - & + & - & + \\
\hline Terpenes & - & + & - & + \\
\hline Phenols & + & + & + & + \\
\hline & Presence & & & \\
- & Absence & & &
\end{tabular}

Table 2: Phytochemical Screening of Plants used in the study. 
Citation: Ilondu EM, Bosah BO (2015) Growth inhibition potentials of Leaf Extracts from Four Selected Euphorbiaceae against Fruit Rot Fungi of African Star Apple (Chrysophyllum albidum G. Don). J Plant Pathol Microb 6: 306. doi:10.4172/2157-7471.1000306

Page 3 of 6

the plants. Alkaloids were present in E. hirta, E. heterophylla and A. fimbriata except $P$. amarus. Flavoinoids was only present in E. hirta. Glycosides and terpenes were present only in E. hirta and A. fimbriata.

The gas chromatography profiles of the plants extracts used in the study were shown in Figures 1-4. The analysis of the extract revealed

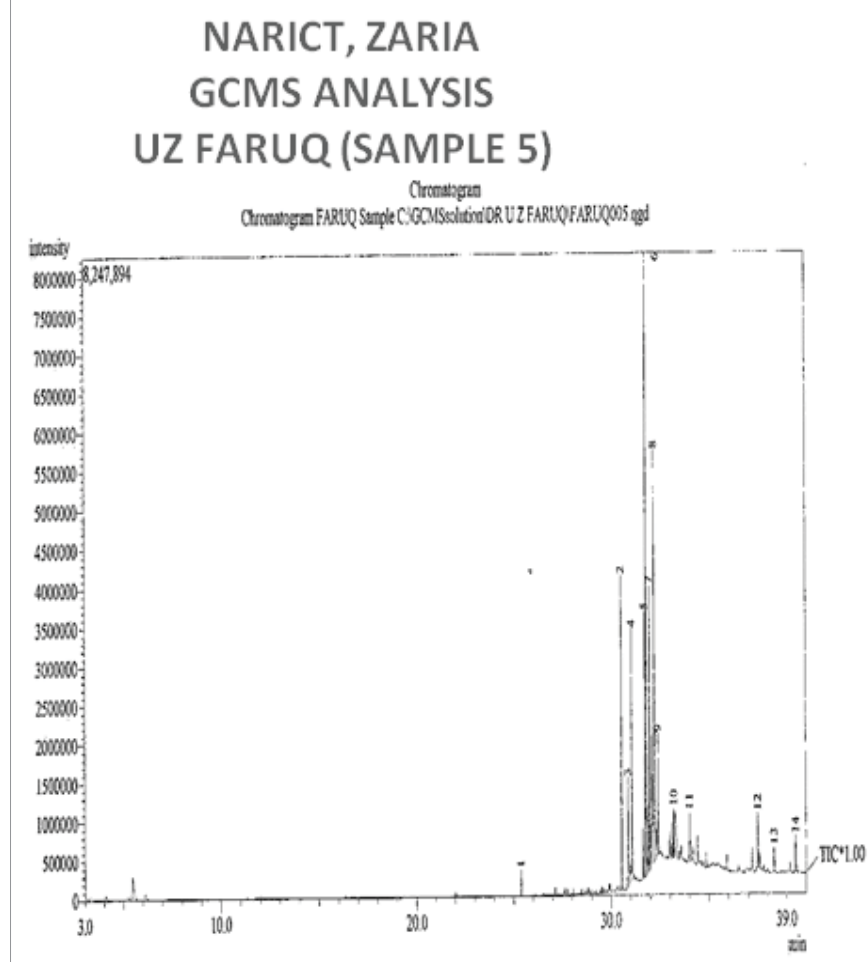

Figure 1: GC-MS Chromatogram for $P$. amarus.

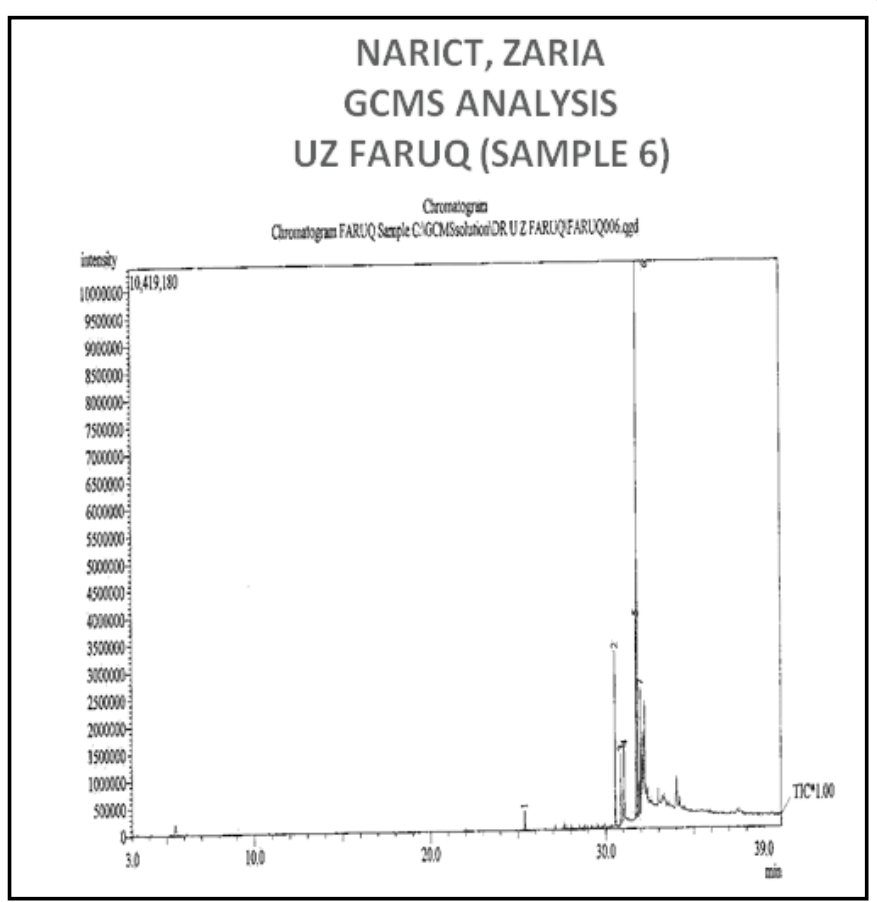

Figure 2: GC-MS Chromatogram for E. hirta.

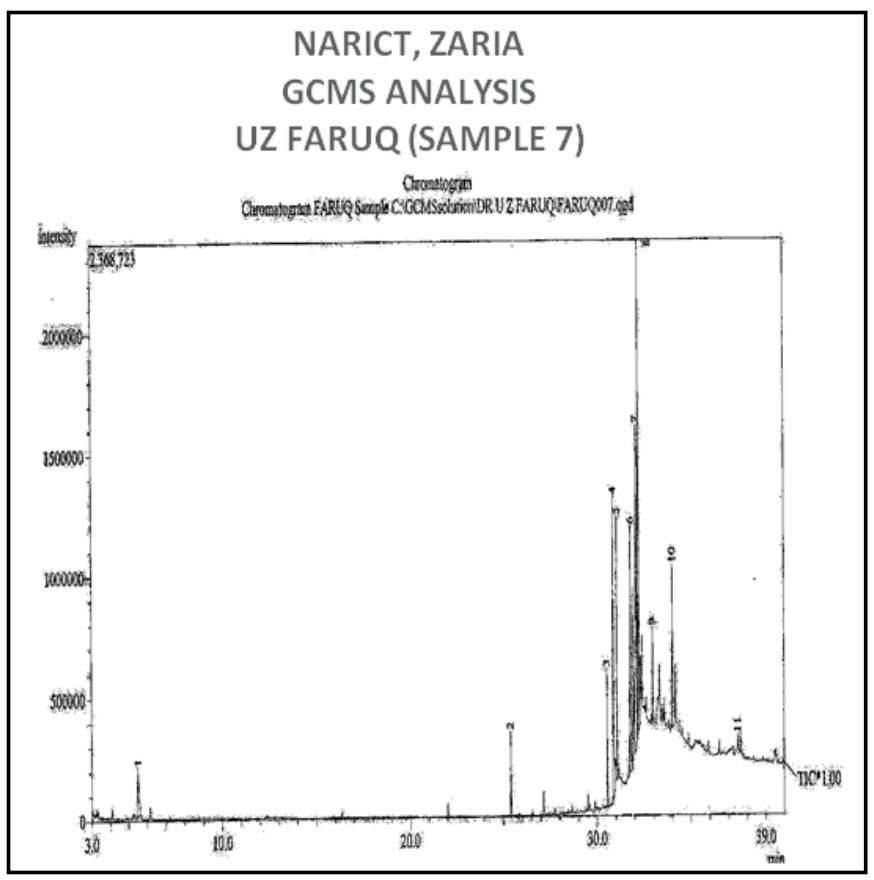

Figure 3: GC-MS Chromatogram for E. heterophylla.

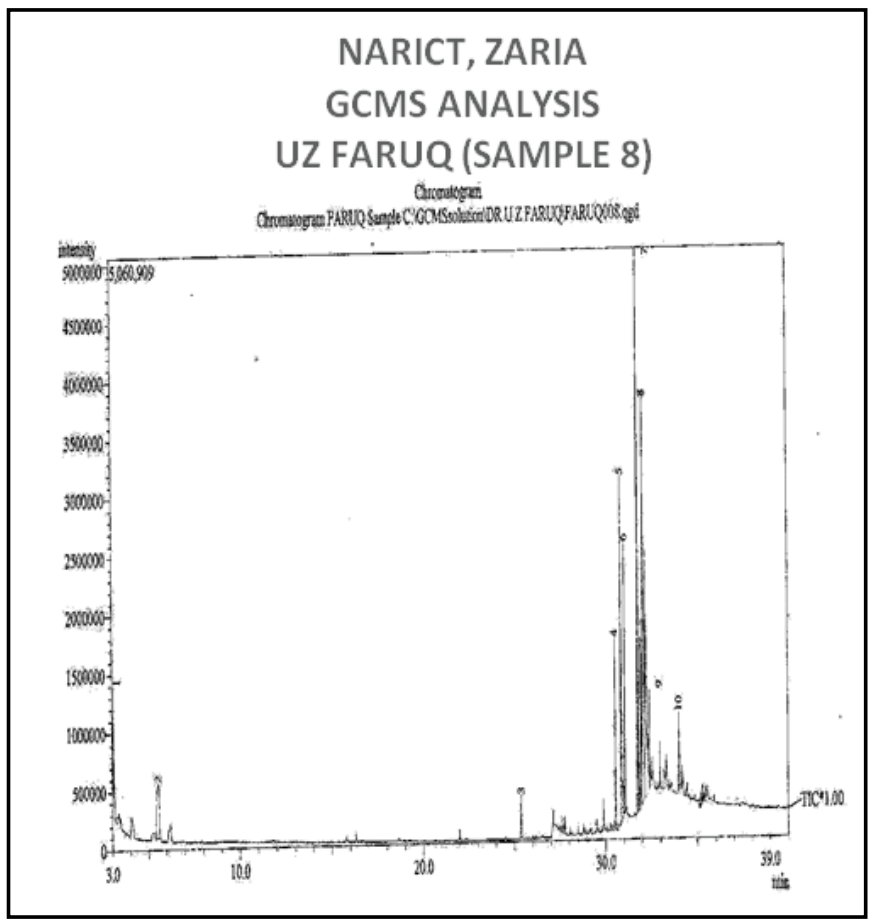

Figure 4: GC-MS Chromatogram for A. fimbriata.

complex mixture of constituents ranging from 7-14 compounds in the samples (Table 3).

Phenol 3,5-bis (1,1-dimethylethyl) were recorded in all plant. Hexadecanoid acid, methyl ester were recorded in all the plant except A. fimbriata. 10-Otadecenoic acid, methyl ester was recorded to be the most abundant of all the (14) compounds identified in P. amarus, 
Citation: Ilondu EM, Bosah BO (2015) Growth inhibition potentials of Leaf Extracts from Four Selected Euphorbiaceae against Fruit Rot Fungi of African Star Apple (Chrysophyllum albidum G. Don). J Plant Pathol Microb 6: 306. doi:10.4172/2157-7471.1000306

Page 4 of 6

\begin{tabular}{|c|c|c|c|c|c|}
\hline Plant Extracts & Peak No & Retention time (min) & $\%$ peak & Compound formula & Name of compound \\
\hline \multirow{14}{*}{ 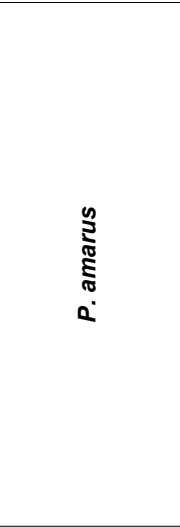 } & 1 & 25.381 & 1.09 & $\mathrm{C}_{14} \mathrm{H}_{22} \mathrm{O}$ & Phenol3,5-bis(1,1-dimethylethyl) \\
\hline & 2 & 30.543 & 9.45 & $\mathrm{C}_{17} \mathrm{H}_{34} \mathrm{O}_{2}$ & Hexadecanoic acid, methyl ester \\
\hline & 3 & 30.868 & 5.51 & $\mathrm{C}_{16} \mathrm{H}_{36} \mathrm{O}_{2}$ & n-Hexadecanoic acid \\
\hline & 4 & 31.066 & 9.17 & $\mathrm{C}_{18} \mathrm{H}_{36} \mathrm{O}_{2}$ & Hexadecanoic acid, ethyl ester \\
\hline & 5 & 31.745 & 9.50 & $\mathrm{C}_{19} \mathrm{H}_{34} \mathrm{O}_{2}$ & 11,14-octadecadienoc acid, methyl ester \\
\hline & 6 & 31.802 & 22.92 & $\mathrm{C}_{19} \mathrm{H}_{34} \mathrm{O}_{2}$ & 10-octadecenoic acid, methyl ester \\
\hline & 7 & 31.978 & 8.69 & $\mathrm{C}_{19} \mathrm{H}_{38} \mathrm{O}_{2}$ & Octadecanoic acid, methyl ester \\
\hline & 8 & 32.223 & 19.33 & $\mathrm{C}_{20} \mathrm{H}_{34} \mathrm{O}_{2}$ & $9,12,15$-octadealrienoic acid, ethyl ester $(z, z, z)$ \\
\hline & 9 & 32.405 & 3.85 & $\mathrm{C}_{20} \mathrm{H}_{40} \mathrm{O}_{2}$ & Octadecanoic acid, ethyl ester \\
\hline & 10 & 33.205 & 1.99 & $\mathrm{C}_{21} \mathrm{H}_{42} \mathrm{O}_{2}$ & Eicosanoic acid, methyl ester \\
\hline & 11 & 34.017 & 2.31 & $\mathrm{C}_{18} \mathrm{H}_{31} \mathrm{C}_{10}$ & 9,12-octadecadienoyl chloride $(z, z)$ \\
\hline & 12 & 37.501 & 2.71 & $\mathrm{C}_{22} \mathrm{H}_{28} \mathrm{O}_{7}$ & Carissanol dimethyl ether \\
\hline & 13 & 38.330 & 1.20 & $\mathrm{C}_{34} \mathrm{H}_{22}$ & Dibenz(a,h) anthracene, 12-diphenyl \\
\hline & 14 & 39.463 & 2.29 & $\mathrm{C}_{10} \mathrm{H}_{14} \mathrm{O}_{2}$ & Benzene, 4-ethyl-2-dimethoxy- \\
\hline \multirow{7}{*}{ 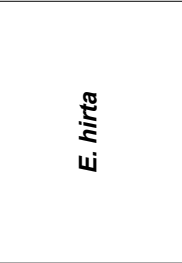 } & 1 & 25.383 & 1.94 & $\mathrm{C}_{14} \mathrm{H}_{22} \mathrm{O}$ & Phenol, 3,5-bis(1,1-dimethylethyl) \\
\hline & 2 & 30.542 & 12.68 & $\mathrm{C}_{17} \mathrm{H}_{34} \mathrm{O}_{2}$ & Hexadecanoic acid, methyl ester \\
\hline & 3 & 30.869 & 8.85 & $\mathrm{C}_{16} \mathrm{H}_{32} \mathrm{O}_{2}$ & n-hexadecanoic acid \\
\hline & 4 & 31.067 & 6.33 & $\mathrm{C}_{18} \mathrm{H}_{36} \mathrm{O}_{2}$ & Hexadecanoic acid, ethyl ester \\
\hline & 5 & 31.747 & 16.27 & $\mathrm{C}_{19} \mathrm{H}_{34} \mathrm{O}_{2}$ & 9,12-octadecadienoic acid methyl ester \\
\hline & 6 & 31.806 & 44.9 & $\mathrm{C}_{19} \mathrm{H}_{36} \mathrm{O}_{2}$ & 9-octadecenoic acid (z)-, methyl ester \\
\hline & 7 & 31.98 & 9.33 & $\mathrm{C}_{19} \mathrm{H}_{38} \mathrm{O}_{2}$ & Octadecanoic acid, methyl ester \\
\hline \multirow{11}{*}{ 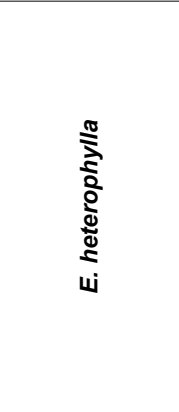 } & 1 & 5.496 & 4.78 & $\mathrm{C}_{8} \mathrm{H}_{10}$ & O-xylene \\
\hline & 2 & 25.386 & 3.47 & $\mathrm{C}_{14} \mathrm{H}_{22} \mathrm{O}$ & Phenol3,5-bis(1,1-dimethylethyl) \\
\hline & 3 & 30.542 & 3.94 & $\mathrm{C}_{17} \mathrm{H}_{34} \mathrm{O}_{2}$ & Hexadecanoic acid, methyl ester \\
\hline & 4 & 30.868 & 14.71 & $\mathrm{C}_{16} \mathrm{H}_{32} \mathrm{O}_{2}$ & n-Hexadecanoic acid, methyl ester \\
\hline & 5 & 31.061 & 7.84 & $\mathrm{C}_{18} \mathrm{H}_{36} \mathrm{O}_{2}$ & Hexadecanoic acid, ethyl ester \\
\hline & 6 & 31.798 & 9.22 & $\mathrm{C}_{19} \mathrm{H}_{36} \mathrm{O}_{2}$ & 10-Octadecenoic acid, methyl ester \\
\hline & 7 & 32.093 & 22.22 & $\mathrm{C}_{22} \mathrm{H}_{42} \mathrm{O}_{2}$ & Erucic acid \\
\hline & 8 & 32.224 & 21.39 & $\mathrm{C}_{18} \mathrm{H}_{32} \mathrm{O}_{2}$ & 9,12-Octadecadienoica cid $(\mathrm{z}, \mathrm{z})$ - \\
\hline & 9 & 32.944 & 2.97 & $\mathrm{C}_{37} \mathrm{H}_{74} \mathrm{NO}_{8} \mathrm{P}$ & Hexadecanoic acid \\
\hline & 10 & 34.020 & 8.33 & $\mathrm{C}_{18} \mathrm{H}_{34} \mathrm{O}$ & 13-Octadecenal \\
\hline & 11 & 37.644 & 1.13 & $\mathrm{C}_{10} \mathrm{H}_{14} \mathrm{O}_{2}$ & 1,4-Benzenedimethanol, alpha, alpha, dimethyl \\
\hline \multirow{10}{*}{ 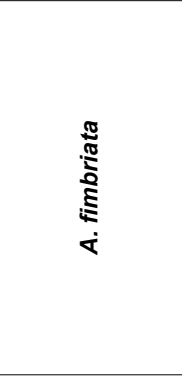 } & 1 & 3.070 & 2.42 & $\mathrm{C}_{5} \mathrm{H}_{12} \mathrm{O}$ & 1-Butanol,3-methyl-/isopentyl alcohol \\
\hline & 2 & 5.43 & 10.52 & $\mathrm{C}_{8} \mathrm{H}_{10}$ & Xylene/benzene1,2-dimethyl \\
\hline & 3 & 25.372 & 1.70 & $\mathrm{C}_{14} \mathrm{H}_{32} \mathrm{O}$ & Phenol3,5-bis(1,1-dimethyl ethyl) \\
\hline & 4 & 30.537 & 5.83 & $\mathrm{C}_{17} \mathrm{H}_{34} \mathrm{O}_{2}$ & Pentadecanoic acid \\
\hline & 5 & 30.867 & 17.42 & $\mathrm{C}_{16} \mathrm{H}_{32} \mathrm{O}_{2}$ & n-Hexadecanoic acid \\
\hline & 6 & 31.057 & 7.95 & $\mathrm{C}_{18} \mathrm{H}_{36} \mathrm{O}_{2}$ & Hexadecanoic acid ethyl ester \\
\hline & 7 & 31.797 & 18.47 & $\mathrm{C}_{19} \mathrm{H}_{36} \mathrm{O}_{2}$ & 10-Octadecenoic acid, methyl ester \\
\hline & 8 & 32.093 & 28.88 & $\mathrm{C}_{22} \mathrm{H}_{42} \mathrm{O}_{2}$ & Erucic acid \\
\hline & 9 & 32.401 & 3.25 & $\mathrm{C}_{20} \mathrm{H}_{40} \mathrm{O}_{2}$ & Octadecanoic acid, ethyl ester \\
\hline & 10 & 34.015 & 3.56 & $\mathrm{C}_{16} \mathrm{H}_{30} \mathrm{O}$ & Cis-9-Hexadecenal \\
\hline
\end{tabular}

Table 3: Major identified constituents of the plant extracts.

9-Octadecenoic acid (Z)-methyl ester was most abundant among the (7) compounds in E. hirta, Erucic acid was most abundant in $E$. heterophylla and A. fimbriata.

The two fungi were very sensitive to various concentrations of the plant extracts tested since the extracts significantly reduced the mycelia growth of the fungi at all concentrations (Table 4). However, the effectiveness of the plant extracts increased with increased in concentration and this was significantly different $(\mathrm{p}<0.05)$ when compared to the control. Similarly, percentage growth inhibition generally increased with increase in concentration of the leaf extracts when compared to the control. Although, the plant extracts could not give complete inhibition at the highest concentration tested, their effectiveness increased with increase concentrations.

There was no significant difference in the inhibitory effect of P. amarus on A. niger at the concentrations of 20 and $40 \mathrm{mg} / \mathrm{ml}, 60$ and $80 \mathrm{mg} / \mathrm{ml}$ concentrations with E. heterophylla as well as 80 and $100 \mathrm{mg} / \mathrm{ml}$ concentrations with A. fimbriata. Similarly, there was no significant difference in the inhibitory effect of $A$. fimbriata extract on F. solani from $60-100 \mathrm{mg} / \mathrm{ml}$ concentrations (Table 5). A. niger was most sensitive to E. heterophylla followed by A. fimbriata, P. amarus and $E$. hirta respectively. Similarly, $F$. solani was most sensitive to $A$. fimbriata followed by E. heterophylla, E. hirta and P. amarus.

\section{Discussion}

The present study showed that two fungi were associated with post harvest fruit rot disease of Chrysophyllum albidum, which include Aspergillus niger and Fusarium solani. These fungi have previously been reported as fruit rot pathogens $[13,19,20]$.

Aspergillus niger has the highest percentage occurrence of $69.6 \%$ followed by F. solani which is $30.4 \%$. This was enhanced by the light 
Citation: Ilondu EM, Bosah BO (2015) Growth inhibition potentials of Leaf Extracts from Four Selected Euphorbiaceae against Fruit Rot Fungi of African Star Apple (Chrysophyllum albidum G. Don). J Plant Pathol Microb 6: 306. doi:10.4172/2157-7471.1000306

Page 5 of 6

\begin{tabular}{|c|c|c|c|c|c|c|c|c|}
\hline \multirow{2}{*}{$\begin{array}{l}\text { Extract conc. (mg/ } \\
\mathrm{ml})\end{array}$} & \multicolumn{2}{|c|}{ P. amarus } & \multicolumn{2}{|c|}{ E. hirta } & \multicolumn{2}{|c|}{ E. heterophyta } & \multicolumn{2}{|c|}{ A. Fimbriata } \\
\hline & A. niger & F. solani & A. niger & F. solani & A. niger & F. solani & A. niger & F. solani \\
\hline 0 & $4.30^{\mathrm{a}}$ & $4.30^{\mathrm{a}}$ & $4.30^{a}$ & $4.30^{\mathrm{a}}$ & $4.30^{\mathrm{a}}$ & $4.30^{\mathrm{a}}$ & $4.30^{\mathrm{a}}$ & $4.30^{\mathrm{a}}$ \\
\hline 20 & $2.07^{b}$ & $3.1^{b}$ & $2.83^{b}$ & $2.83^{b}$ & $1.53^{\mathrm{b}}$ & $1.90^{\mathrm{b}}$ & $1.87^{\mathrm{b}}$ & $1.53^{\mathrm{b}}$ \\
\hline 40 & $1.95^{\mathrm{c}}$ & $2.23^{c}$ & $2.40^{c}$ & $1.93^{\mathrm{c}}$ & $0.95^{c}$ & $1.73^{\mathrm{b}}$ & $1.40^{\mathrm{c}}$ & $0.58^{c}$ \\
\hline 60 & $1.13^{c}$ & $1.85^{\mathrm{d}}$ & $1.97^{\mathrm{d}}$ & $1.63^{c}$ & $0.72^{\mathrm{c}}$ & $0.85^{c}$ & $0.92^{d}$ & $0.42^{\mathrm{c}}$ \\
\hline 80 & $0.92^{\mathrm{d}}$ & $1.27^{\mathrm{e}}$ & $1.50^{\mathrm{e}}$ & $1.03^{d}$ & $0.62^{c}$ & $0.62^{c}$ & $0.75^{d}$ & $0.30^{c}$ \\
\hline 100 & $0.84^{d}$ & $0.92^{f}$ & $1.03^{f}$ & $0.82^{\mathrm{d}}$ & $0.47^{c}$ & $0.42^{\mathrm{c}}$ & $0.60^{d}$ & $0.22^{\mathrm{c}}$ \\
\hline
\end{tabular}

Values with the same superscript(s) in the same column are not significantly different at $\mathrm{P}>0.05$ by DMRT.

Table 4: Radial mycelia growth $(\mathrm{cm})$ of fungi isolated from Chrysophyllum albidum fruits when exposed to various concentrations of plant leaf extracts.

\begin{tabular}{|c|c|c|c|c|c|c|c|c|}
\hline \multirow[t]{2}{*}{ Conc. (\%) } & \multicolumn{2}{|c|}{ P. amarus } & \multicolumn{2}{|c|}{ E. hirta } & \multicolumn{2}{|c|}{ E. heterophylla } & \multicolumn{2}{|c|}{ A. fimbriata } \\
\hline & F. Solani & A. niger & F. Solani & A. niger & F. Solani & A. niger & F. Solani & A. niger \\
\hline 0 & $0^{f}$ & $0^{d}$ & $0^{f}$ & $0^{f}$ & $0^{f}$ & $0^{e}$ & $0^{d}$ & $0^{d}$ \\
\hline 20 & $27.91^{\mathrm{e}}$ & $51.86^{d}$ & $45.81^{e}$ & $34.19^{e}$ & $55.51^{e}$ & $64.42^{\mathrm{d}}$ & $64.42^{c}$ & $56.51^{c}$ \\
\hline 40 & $48.14^{\mathrm{d}}$ & $54.65^{c}$ & $55.43^{d}$ & $44.18^{d}$ & $59.77^{d}$ & $77.91^{\circ}$ & $86.49^{b}$ & $67.44^{\mathrm{b}}$ \\
\hline 60 & $56.98^{c}$ & $73.72^{\mathrm{b}}$ & $62.09^{c}$ & $54.19^{\circ}$ & $80.37^{\circ}$ & $83.43^{b}$ & $90.23^{a}$ & $78.75^{\mathrm{ab}}$ \\
\hline 80 & $70.47^{\mathrm{b}}$ & $78.61^{a}$ & $76.21^{b}$ & $65.12^{\mathrm{b}}$ & $85.58^{b}$ & $85.58^{b}$ & $93.02^{\mathrm{a}}$ & $82.68^{a}$ \\
\hline 100 & $78.61^{a}$ & $80.47^{a}$ & $80.93^{a}$ & $76.05^{a}$ & $90.31^{a}$ & $89.07^{a}$ & $94.89^{a}$ & $86.05^{\mathrm{a}}$ \\
\hline
\end{tabular}

Values with the same superscript(s) in the same column are not significantly different at $\mathrm{P}>0.05$ by DMRT.

Table 5: Percentage growth inhibition of fungal isolates from Chrysophyllum albidum fruits after exposure to varying concentrations of leaf extract of various plants.

spores, which are easily dispersed by wind. Similarly Aspergillus species are capable of utilizing an enormous variety of substrates as the result of large number of enzymes they produce [21].

Phytochemical screening of the plants revealed the presence of saponin, alkaloid, tanin, steroids, Phenols, terpenes, glycosides, and flavonoids. The presence of these secondary metabolites could be responsible for their antifungal activity. Egwin et al. have earlier demonstrated the presence of tannins in Euphorbia hirta and opined that it may account for its antimicrobial activity. Tannins have been reported to be toxic to bacteria, filamentous fungal and yeast [22]. Ogbo and Oyibo [19] reported that the presence of alkaloids, saponins and terpenoids in the extract of Ocimum gratissimum may have accounted for the broad spectrum of activities on the fungal isolate tested.

The analysis of the plant extract of the leaves in this study showed a complex mixture of constituents. The total number of compounds identified varied from 7-14 in all the plant samples. It is possible that these compounds identified in the plant extracts were responsible for the observed fungi-toxic effects in the study. Sunderham [23] reported that the toxic action of the plant extract of E. heterophylla is due to the combined action of its constituents this is similar to the observations of Ilondu $[14,16]$.

Erucic acid was the highest constituent found in E. heterophylla (22.22\%) and A. fambiata (28.88\%) extracts. Antimicrobial activity of Eruca sativa seed oil has been reported to be due to higher concentration of erucic acid present in the oil $[24,25]$. Varied concentrations of fatty acid including their ethyl and methyl esters were found abundant in all the plant extracts. Several researchers have reported the antifungal activity of fatty acid and their ethyl and methyl esters against pathogenic fungi $[14,16,26]$.

The percentage inhibition of the mycelia growth of the tested fungi was found to increase as concentration of the plant extracts increased. This may be as a result of the presence of the biologically active antimicrobial compounds of the extracts in higher quantity at lower dilutions, this findings is in consonance with the work of Fernadex et al. [27] who suggested that with increasing concentrations the antagonistic property of the extract increased.
The above result clearly confirms that the test fungi varied widely in the degree of their susceptibility to the extracts. The extract of Euphorbia heterophylla was the most effective of all the extracts in inhibiting the growth of Aspergillus niger followed by Acalypha fimbriata, Phyllanthus amaraus and Euphorbia hirta. While ethanolic extracts of Acalypha fimbriata was the most effective in inhibiting the growth of Fusarium solani followed by Ephorbia heterophylla, Euphorbia hirta and Phyllanthus amarus. Previous studies have shown that ethanolic leaf extracts of E. hirta, E. heterophylla, A. fimbriata, $P$. amarus and other species of these genera were capable of inhibiting the growth of bacteria, and fungi $[13,23,28-32]$.

\section{Conclusion}

The result of this study is an indication that these Euphorbiaceae could be a potential source of antifungal agents. Knowledge of chemical constituents of non-economic plants is desirable because such information could be valuable in discovering new source of economic materials, which may be precursors for the synthesis of complex chemical substances. Such screening of various natural organic compounds and identification of active agents is the need of the century for the formulation of plant biofungicide and improvement of food security for the timing world population.

\section{References}

1. Ehiagbonare JE, Oniyibe $\mathrm{HI}$, Okoegwale $\mathrm{EE}$ (2008) Studies on the isolation of normal and abnormal seedling of Chrysophyllum albidum: A step towards sustainable management of the taxon in the 21 st century. Science Research Essay 3: $567-570$.

2. Amusa NA, Ashaye OA Oladapo MO (2003) Biodeterioration of African sta apple (Chrysophyllum albidum) in storage and the effect on its food value. African Journal of Biotechnology 2: 56-59.

3. Agbogidi OM, Ilondu EM (2012) Heavy metal contents of Gambaya albida (Linn.) seedlings growth in soil contaminated with crude oil. Journal of Biological and Chemical Research 29: 320-325.

4. Bada SO (1997) Preliminary information on the ecology of Chrysophyllum albidum G.Don in West Central Africa. In: Denton OA, Ladipo DO, Adetoro MA and Sarumi MB (Eds.). Proceedings of a National Workshops on the potentials of star apple in Nigeria, pp:16-25.

5. Umoh IB (1998) Commonly used fruits in Nigeria In: Osagie, A.U. and Eka 
Citation: Ilondu EM, Bosah BO (2015) Growth inhibition potentials of Leaf Extracts from Four Selected Euphorbiaceae against Fruit Rot Fungi of African Star Apple (Chrysophyllum albidum G. Don). J Plant Pathol Microb 6: 306. doi:10.4172/2157-7471.1000306

O.U. (Eds.). Nutritional quality of plant foods. Post-Harvest Research Unit, Department of Biochemistry, University of Benin, Benin City, Nigeria, pp: 84-120.

6. Ureigho UN (2010) Nutrient values of Chrysophyllum albidum Linn African star apple as a domestic income plantation species. African research review 4: 50-56.

7. Okoli BJ, Okere OS (2010) Antimicrobial activity of the phytochemical constituents of Chrysophyllum albidum G. Don-Holl (African star apple). Journal of Research In National Development 8: 1-7.

8. Oboh IO, Aluyor EO, Audu TOK (2009) Use of Chrysophyllum albidum for the removal of metal ions from aqueous solution. Scientific Research and Essay 4: 632-635.

9. Olorunnisola DS, Amao IS, Ehigie DO, Ajayi ZAF (2008) Antihyperglycernie and hyperlipidemic effect of ethanolic extracts of Chrysophyllum albidum seed cotyledon in Alloxan induced-diabetic rats. Research Journal of Applied Science 3: 123-127.

10. Kazeem-Ibrahim F, Asinwa IO, Iroko OA, Aiyeyika AK, Fapojuwomi OA (2013) Investigation of fungi associated with the spoilage of Chrysophyllum albidum (G.Don) fruits. WebPub Journal of Agricultural Research 1: 56-60.

11. Efe SI (2007) The climate of Delta State, Nigeria. In: Odemerho FO, Awaritefe OD, Atubi AO, Ugbomeh BA and Efe SI (Eds.) Delta State in Maps; Department of Geography and Regional Planning, Delta State University Abraka, Nigeria. pp: 24-30.

12. Akobundu IO, Agyakwa CW (1998) A Handbook of West African weeds 2nd edition. International Institute of Tropical Agriculture, Ibadan, Nigeria pp: 564

13. Ilondu EM (2011) Evaluation of some aqueous plant extracts used in the contro of pawpaw fruit (Carica papaya L.) rot fungi. Journal of Applied Biosciences 37: 2419-2424.

14. Ilondu EM (2013b) Phytochemical composition and efficacy of ethanolic lea extracts of some Vernonia species against two phytopathogenic fungi. Journal of Biopesticides 6: 165-172

15. Oyewale AO, Audu OT (2007) The medicinal potentials of aqueous and methanol extracts of six flora of tropical Africa. Journal of Chemical Society of Nigeria 32: 150-155

16. Ilondu EM (2013a) Chemical constituents and comparative toxicity of Aspilia africana (pers) C.D Adams leaf extractives against two leafspot fungal isolates of Paw-paw (Carica papaya L.). Indian Journal of Science and Technology 6 : $5242-5248$.

17. Chohan S, Atiq R, mehmoo MA, Naz S, siddique B, et al. (2011) Efficacy of few plant extracts against Fusarium oxysporium F.sp gladioli, the cause of corm rot of gladiolus. Journal of Medicinal Plant Research 5: 3887-3890.

18. Ayodele SM, Ilondu EM, Onwubolu NC (2009) Antifungal properties of some locally used spices in Nigeria against some rot fungi. African Journal of Plant Science 3: 139-141.
19. Ogbo EM, Oyibo A (2008) Effects of three plant extracts (Ocimum grattissimum, Acalypha wilkesiana and Acalypha macrostachya) on post-harvest pathogen of Persea americana. Journal of Medicinal Plants Research 2: 311-315.

20. Ilondu EM, Echigeme MV, Isitohan FO (2015) Bioactive principles and antifungal activity of acetone extract fractions of three tropical spices against Aspergillus niger causing fruit rot of African pear (Dacryodes edulis). In: Book of Abstract and Programme, 40th Annual Conference of Nigerian Society for Plant Protection (NSPP) Abuja, pp: 36.

21. Alexopoulus CJ, Minms CW, Blackwell M (2002) Introductory mycology. 4th Edition. John Wiley and Sons Inc., Singapore, pp: 869.

22. Harborne BJ (1992) Phytochemical methods: A guide to modern techniques of Plant Analysis, 3rd Edition, Chapman and Hall, London, pp: 58.

23. Sunderham M (2010) Antimicrobial and Anticancer studies on Euphorbia heterophylla. Journal of Pharmacy Research 3: 2332-2333.

24. Khoobchandani M, Ojeswi BK, Ganesh N, Srivastava MM, Gabbanini S, et al. (2010) Antimicrobial properties and analytical profile of traditional Eruca sativa seed oil: Comparison with various aerial and root plant extracts. Food Chemistry 120: 217-224.

25. Gulfaraz M, Sadiq A, Tariq H, Imran M, Qureshi R, et al. (2011) Phytochemical analysis and antibacterial activity of Eruca sativa seed. Pakistan Journal of Botany 43: 1351-1359.

26. Chandrasekaran M, Senthilkumar A, Venkatesalu V (2011) Antibacterial and antifungal efficacy of fatty acid methyl esters from the leaves of Sesuvium portulacastrum L. European Review for Medicinal and Pharmacological Science 15: 775-780.

27. Fernández MA, García MD, Sáenz MT (1996) Antibacterial activity of the phenolic acids fractions of Scrophularia frutescens and Scrophularia sambucifolia. J Ethnopharmacol 53: 11-14.

28. Emele FE, Agbonlahor DE, Emakpare Cl (1997) Antimcrobial activity of Euphorbia hirta leaves collected from two geographically dissimilar regions of Nigeria. Nigerian Journal of Microbiology 11: 5-10.

29. Brown PD, Izundu A (2004) Antibiotic resistance in clinical isolates of Pseudomonas aeruginosa in Jamaica. Rev Panam Salud Publica 16: 125-130.

30. Onyeke CC, Maduewesi JNC (2006) Evaluation of some plant extracts for the control of post-harvest fungal diseases of Banana (Musa sapientus Linn). Fruit in South-Eastern Nigeria. Nigerian Journal of Botany 19: 129-137.

31. Bhaskara KV (2010) Antibacterial and antifungal activities of Euphorbia hirta leaves. Journal of Pharmacy Research 3: 548-549.

32. Evans CE, Banso A, Samuel OA (2002) Efficacy of some nupe medicinal plants against Salmonella typhi: an in vitro study. J Ethnopharmacol 80: 21-24. 